九州大学学術情報リポジトリ

Kyushu University Institutional Repository

\title{
Heavy Metal of Soil in Wastewater - Irrigated Agricultural Soil in a Surrounding Area of the Nhue River, Vietnam
}

Nguyen, Thi Lan Huong

Water Resources University

Kanayama, Motohe i

Laboratory of Environmental Soil Engineering, Department of Environmental Sciences for Sustainability, Faculty of Agriculture, Iwate University

Higashi, Takahiro

Division of Bioproduction Environmental Sciences, Department of Agro-Environmental Sciences, Faculty of Agriculture, Kyushu University

Le, Van Chinh

Water Resources University

他

https://doi.org/10.5109/1434405

出版情報：九州大学大学院農学研究院紀要. 59 (1)，pp. 149-154，2014-02-28. Faculty of Agriculture, Kyushu University

バージョン :

権利関係 : 


\title{
Heavy Metal of Soil in Wastewater - Irrigated Agricultural Soil in a Surrounding Area of the Nhue River, Vietnam
}

\section{Thi Lan Huong NGUYEN ${ }^{*}$, Motohei KANAYAMA², Takahiro HIGASHI, Van Chinh $\mathrm{LE}^{1}$, Thu Ha DOAN ${ }^{1}$ and Anh Dao CHU ${ }^{3}$}

\author{
Laboratory of Environmental Soil Engineering, Division of Bioproduction Environmental Sciences, \\ Department of Agro-Environmental Sciences, Faculty of Agriculture, \\ Kyushu University, Fukuoka 812-8581, Japan \\ (Received October 17, 2013 and accepted November 11, 2013)
}

\begin{abstract}
Waste from industrial sources, serves as sources of water for irrigating farms. The purpose of this study is to identify the impact of waste-water irrigation on the level of heavy metals in the soils. Soil samples were collected from the different locations from upstream to downstream of the Nhue River to evaluate heavy metal pollution.The results showed that the concentrations of all heavy metals in the soil samples in the farmland area were much higher than the background level in that area (1.2-2.6 mg/kg for Cd, 42-60 mg/kg for $\mathrm{Cr}, 22-62 \mathrm{mg} / \mathrm{kg}$ for $\mathrm{Cu}, 30-86 \mathrm{mg} / \mathrm{kg}$ for $\mathrm{Pb}, 119-245 \mathrm{mg} / \mathrm{kg}$ for $\mathrm{Zn}$, and $26-57 \mathrm{mg} / \mathrm{kg}$ for $\mathrm{Ni}$ ), and exceeded the level of Vietnamese standard for agricultural soil for all heavy metals $\mathrm{Cd}, \mathrm{Cu}, \mathrm{Pb}$ and $\mathrm{Zn}$ except soil samples at upstream and downstream of the Nhue River.
\end{abstract}

Key words: heavy metal, Nhue River, soil, wastewater irrigation

\section{INTRODUCTION}

Heavy metal contamination of soil resulting from wastewater irrigation is a cause of serious concern due to the potential health impacts of consuming contaminated produce. In suburban areas, the use of industrial or municipal wastewater is common practice in many parts of the world (Feiginet al., 1991), including Vietnam (Nguyen et al., 2007). Access to adequate water for irrigation is a matter of increasing concern in Vietnam. To face the growing demand for irrigation water, nonconventional resources are often used. Importance sources of heavy metals in wastewater are urban and industrial effluents, deterioration of sewage pipe and treatment works, and the wear of household plumbing fixtures. Wastewater irrigation is known to contribute significantly to the heavy metal content of soils (Singh et al., 2004). A number of previous studies from developing countries have reported heavy metal contamination in wastewater and wastewater-irrigated soil (Mapanda et al., 2005; Singh et al., 2004). However, there are very few empirical data from Vietnam for heavy metal contamination of water and its transfers to the soil.

Accumulation of heavy metals in the soil, especially in upper horizons, eventually could cause serious problems, resulting in health risks if they enter the food chain. Heavy metal concentrations in soil are typically

\footnotetext{
1 Water Resources University, Vietnam, 175 Tay Son, Dong Da, Hanoi, Vietnam

2 Laboratory of Environmental Soil Engineering, Department of Environmental Sciences for Sustainability, Faculty of Agriculture, Iwate University, 3-18-8 Ueda, Morioka, Iwate 020-8550, Japan

3 Institution of Industrial Chemistry of Vietnam, 2 Pham Ngu Lao, HoanKiem, Hanoi, Vietnam

* Corresponding author (E-mail: nl_huong_99@yahoo.com)
}

quantified and regulated on the basis of total metal content, regardless of their solubility. However, soils with large amount of colloidal organic and mineral material can sorb and immobilize these metals to greater extent than soils with a low content of these reactive materials.

Recently, increasing industrialization and population growth have led to increasing fluxes of many heavy metals to soils of the To Lich and Kim Nguu river system in Hanoi City, Vietnam (Ho and Egashira, 2000). This has also great relevance to the Hanoi agro-ecosystem, where the wastes produced in urban and industrial areas provide the most likely sources of heavy metal pollution, and the dominant sources of soil heavy metal pollution are sewage irrigation. Water used for irrigation in agricultural soil of Hanoi City is seriously polluted by industrial wastewater (Nguyen et al., 2007). In the long term, irrigation may cause the accumulation of heavymetals at toxic concentrations in the soil and adversely affect both soil microbiological processes and plant growth.

The present study is based on agricultural soil at the surrounding area of the NhueRiver, Vietnam which is estimated as one of the most polluted agricultural soil areas, and where wastewater from the NhueRiver has been commonly used for irrigation of peri-urban crops for several decades. Study on the pollution of the Nhue River in Vietnam has a relatively short history and has been conducted by a few authors. Kikuchi et al. (2009) discussed heavy metal pollution in the water of the Nhue River by using multivariate analyses. Trinh et al. (2007) studied about the impact of waste water from industrial activities. The objective of this study is to assess the effects of polluted irrigation water on the quality of farmland soil in the Nhue River basin. 


\section{MATERIALS AND METHODS}

\section{Materials}

Forty surface soil samples and surface water samples were collected from 10 locations alongthe Nhue River, referred as SS1 to SS 10 and WS 1 to WS 10 (Fig. 1). At each location samples were taken in four times: December 2011; March, June and August 2012. The soil samples were air-dried, disaggregated, passed through a 1-mm sieve, and preserved in plastic bottles at room temperature for analysis (Ho et al.,1998).

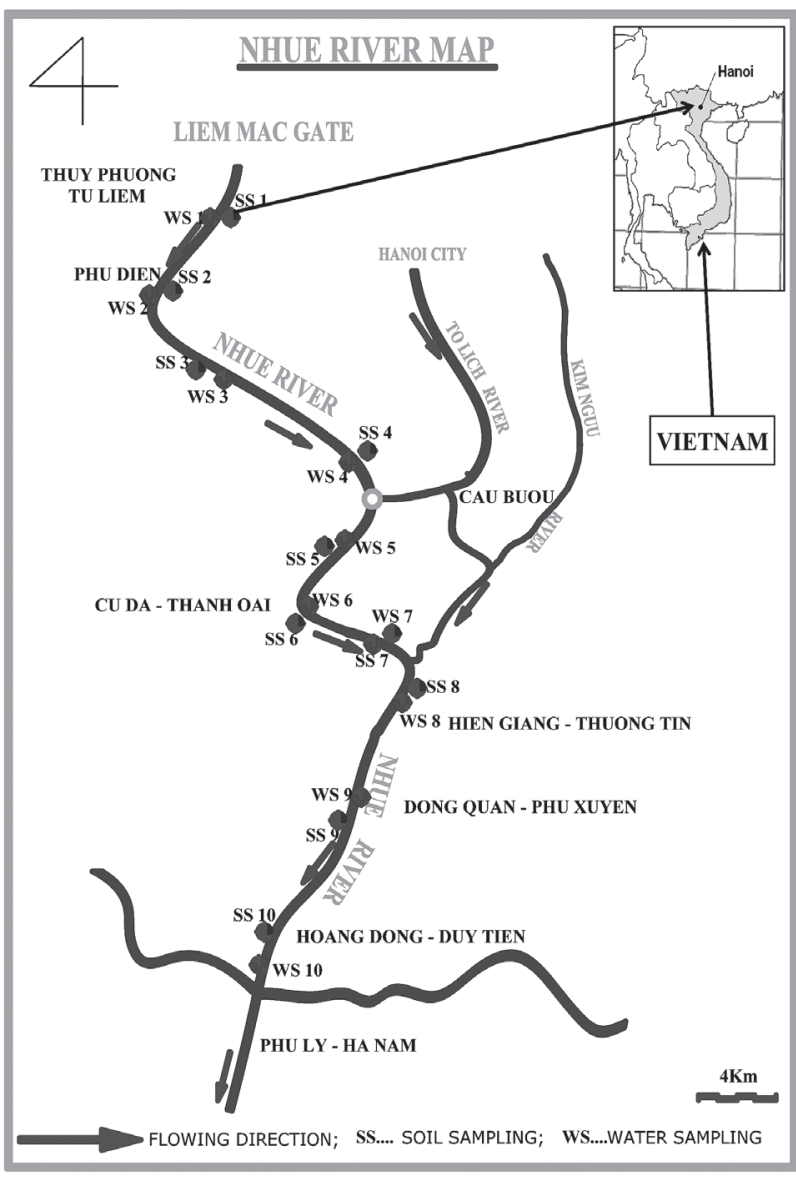

Fig. 1. Site sampling location.

\section{Methodology}

Chemical and Physical Properties of Soil

The $\mathrm{pH}$ was measured using soil suspension with soil(dry)-to-water ratio of 1:2.5. Organic carbon (OC) contents were determined by Tyurin method, and the organic matter concentration were calculated by multiplying OC values by the coefficient of 1.724 (Committee of Soil Standard Methods for Analyses and Measurements, 1986). Electric conductivity (EC) was determined using conductivity meter (CM 20S TOA). Cation exchange capacity (CEC) and exchangeable cations were measured by the method proposed by Muramoto et al. (1992).

In the particle-size analysis, $10 \mathrm{~g}$ of an air-dried soil/sediment sample was treated with $7 \%$ water to remove organic matter, dispersed by ultrasonic vibra- tion (tank-type; $38 \mathrm{kHz}, 250 \mathrm{~W}$ ), and deflocculated by adjusting $\mathrm{pH}$ to 10 with addition of $1 \mathrm{M} \mathrm{NaOH}$. After sedimentation for a fixed period of time, the clay fraction $(<2 \mu \mathrm{m})$ was siphoned out. With repetition of sonication (50T)-sedimentation-siphoning with intermittent $\mathrm{pH}$ adjustment, the whole clay fraction was separated. The silt fraction $(2-20 \mu \mathrm{m})$ was also separated by repeated sedimentation and siphoning. The fine sand (20-200 $\mu \mathrm{m})$ and coarse sand (200-2000 $\mu \mathrm{m})$ fractions were obtained by wet sieving. After oven-drying at $105^{\circ} \mathrm{C}$, each fraction was weighed to calculate the particle size distribution of a soil/sediment.

For clay mineral analysis, the $<2 \mu$ m clay fractions of the soil/sediment separated in the particle-size analysis was used. Two clay suspensions containing $50 \mathrm{mg}$ clay were prepared. One was saturated with $\mathrm{Mg}^{2+}$ by washing with $0.5 \mathrm{M} \mathrm{MgCl}_{2}$ and the other with $\mathrm{K}^{+}$by $1 \mathrm{M}$ $\mathrm{KCl}$. Excess salt was removed by washing with water. After addition of $1 \mathrm{~mL}$ of water was added and an aliquot of suspension containing $30 \mathrm{mg}$ of clay was deposited onto a glass slide, air-dried, and X-rayed. The $\mathrm{K}$-saturated specimen was heated at $300^{\circ} \mathrm{C}$ and $550^{\circ} \mathrm{C}$ for $1 \mathrm{hr}$, and measured after each treatment. The Mg-saturated specimen was solvated with glycerol before a further analysis. The specimen thus treated was X-rayed under $10 \mathrm{~mA}$ and $30 \mathrm{kV}$. Filtered $\mathrm{CoK} \alpha$ or $\mathrm{CuK} \alpha$ radiation from Rigaku diffract meter were used for X-ray diffraction. Relative mineral contents in the clay fractions were estimated based on the peak intensities of XRD (Nguyen and Egashira, 2005).

\section{Total Heavy Metal Concentration of Water}

Total heavy metal concentrations were determined for non-filtered water samples, respectively. Heavy metals in the water samples were analyzed with atomic absorption spectrophotometer (AAS - Solar S2 Thermo electronic cooperation).

\section{Total Heavy Metal Concentration of Soil}

For total heavy metal concentration, one g of airdried soil/sediment samplewas digested with $5 \mathrm{~mL}$ of concentrated $\mathrm{HNO}_{3}$. The mixture was brought to a slow boil by heating the flask at $96^{\circ} \mathrm{C}$ on a hot plate for $1 \mathrm{hr}$. After the mixture was boiled down to about $2 \mathrm{~mL}, 5 \mathrm{~mL}$ concentrated $\mathrm{HNO}_{3}$ was added. A reflux cap was placed onto the flask, and the mixture was boiled for approximately $2 \mathrm{~h}$. The solution obtained after centrifugation was transferred into $50 \mathrm{~mL}$ volumetric flask and made up to the mark with distilled water after cooling. The solution was analyzed for $\mathrm{Cd}, \mathrm{Cr}, \mathrm{Cu}, \mathrm{Ni}, \mathrm{Pb}$ and $\mathrm{Zn}$ by atomic absorption spectrometry (SOLAAR m, Nippon Jarrel-ash Co., Ltd., Japan). The determination was made in duplicate and the relative deviation of the duplicate values was usually less than $5 \%$.

\section{RESULTS AND DISCUSSIONS}

\section{The Quality of Water}

Water from the Nhue River is used to irrigate agricultural land in surrounding area of Hanoi city. The irri- 
gationwater is heavily polluted with wastes from domestic (60-80\%) and industrial (20-40\%) source (Klank et al., 2006). Table 1 shows the mean value (four times taking sample) ofheavy metal concentration of the water irrigated to the paddy field used for the present study. The total concentrations of heavy metalofalmost irrigation water samples (except water samples were taken from upstream and downstream) exceeded the

Table 1. Heavy metal concentrations of water of the Nhue River

\begin{tabular}{|c|c|c|c|c|c|c|}
\hline \multirow[t]{2}{*}{ No } & \multicolumn{6}{|c|}{$\begin{array}{c}\text { Total heavy metal concentration } \\
\text { Dry season (mg/L) }\end{array}$} \\
\hline & $\mathrm{Cd}$ & $\mathrm{Cr}$ & $\mathrm{Cu}$ & $\mathrm{Ni}$ & $\mathrm{Pb}$ & $\mathrm{Zn}$ \\
\hline WS1 & 0.009 & 0.03 & 0.2 & 0.07 & 0.2 & 1.1 \\
\hline WS2 & 0.09 & 0.09 & 0.4 & 0.09 & 0.3 & 1.3 \\
\hline WS3 & 0.03 & 0.07 & 1.0 & 0.12 & 0.6 & 1.4 \\
\hline WS4 & 0.06 & 0.07 & 1.0 & 0.17 & 0.8 & 1.6 \\
\hline WS5 & 0.06 & 0.07 & 0.9 & 0.25 & 1.1 & 1.7 \\
\hline WS6 & 0.05 & 0.08 & 0.9 & 0.20 & 0.9 & 1.5 \\
\hline WS7 & 0.04 & 0.07 & 0.8 & 0.15 & 0.8 & 1.1 \\
\hline WS8 & 0.05 & 0.06 & 0.9 & 0.23 & 0.8 & 1.5 \\
\hline WS9 & 0.03 & 0.05 & 0.6 & 0.20 & 0.6 & 1.6 \\
\hline WS10 & 0.01 & 0.03 & 0.3 & 0.15 & 0.3 & 1.2 \\
\hline MOSTE ${ }^{* *}$ & 0.01 & 0.04 & 0.5 & 0.1 & 0.5 & 1.5 \\
\hline$W H O * * *$ & 0.01 & 0.1 & 0.2 & 0.2 & 5 & 2 \\
\hline $\begin{array}{r}* \text { pHu } \\
\text { ** } \mathbf{M O S} \\
\text { for } t \\
\text { inclu } \\
\text { *** Irrig }\end{array}$ & $\begin{array}{l}\text { meas } \\
\mathbf{E} \mathbf{0 8} \\
\text { pur } \\
\text { ng ir } \\
\text { ion w }\end{array}$ & $\begin{array}{l}d \text { in } \\
\mathbf{8} \mathbf{B} \mathbf{1} \\
\text { oth } \\
\text { tion } \\
\text { stan }\end{array}$ & $\begin{array}{l}\text { opl } \\
\text { tha } \\
\text { er } \\
d \text { ( }\end{array}$ & $\begin{array}{l}\text { the } \\
\text { mes } \\
198\end{array}$ & face & $\begin{array}{l}\text { r used } \\
\text { ipply, }\end{array}$ \\
\hline
\end{tabular}

permissible level of the Vietnamese standard for irrigation water (MOSTE, 2008).

\section{The Quality of the Soil}

Chemical and Physical Properties of Soil

Table 2 shows the mean value of chemical and physical properties of soil samples (four times taking sample). The $\mathrm{pH}_{(\mathrm{H} 2 \mathrm{O})}$ and $\mathrm{pH}_{(\mathrm{KCl})}$ were in a range of 5.8-6.4 and 5.5 to 6.0 , respectively, suggesting the natural condition of soils was lightly acid. The EC ranged between 0.05 and $0.13 \mathrm{mS} / \mathrm{cm}$. The organic matter content varied from 1.4 to $3.6 \%$. Those values were lower than for the agricultural soil along the To Lich and Kim Nguu Rivers studied by Nguyen et al. (2010a, 2008b). The soil samples from SS1 exhibited the highest organic matter content. The cation exchange capacity (CEC) ranged between 16.9 and $26.4 \mathrm{cmol}_{\mathrm{c}} / \mathrm{kg}$. The exchangeable cations were predominant in $\mathrm{Ca}$, followed by $\mathrm{Mg}, \mathrm{K}$ and $\mathrm{Na}$.

The clay, silt, fine sand and coarse sand fractions ranged from 36.5 to $48.3 \%, 25.1-351.5 \%, 8.9-15.2 \%$ and $11.6-21.8 \%$, being classified as Clay loam (ISSU). These clay contents are higher than those for the soil samples taken from farmland along the To Lich and Kim Nguu Rivers (Nguyen et al., 2010a, 2008b).

The XRD patterns for the $<2 \mu \mathrm{m}$ clay fractions of the soil samples are illustrated in Fig. 2. The presence of mica was indicated by the $1.00 \mathrm{~nm}$ peak along its higher-order reflections at 0.50 and $0.33 \mathrm{~nm}$. The presence of kaolinite was indicated by the peaks at 0.72 and $0.35 \mathrm{~nm}$ in the $\mathrm{K}$-saturated specimen that disappeared at $550^{\circ} \mathrm{C}$. Chlorite was identified by the peaks at 1.43 , $0.72,0.47$ and $0.35 \mathrm{~nm}$. Vermiculite was identified by the peaks at $1.43 \mathrm{~nm}$ in $\mathrm{Mg}$-saturated and $\mathrm{Mg}$-glycerol specimens, and the peak at $1.00 \mathrm{~nm}$ in the $\mathrm{K}$-saturated spec-

Table 2. Chemical and physical properties of the soil samples

\begin{tabular}{|c|c|c|c|c|c|c|c|c|c|c|c|c|c|c|}
\hline \multirow[b]{2}{*}{ Location } & \multirow[b]{2}{*}{$\mathrm{pH}_{(\mathrm{H} 20)}$} & \multirow[b]{2}{*}{$\mathrm{pH}_{(\mathrm{KCl})}$} & \multirow{2}{*}{$\begin{array}{l}\mathrm{EC} \\
(\mathrm{mS} / \\
\mathrm{cm})\end{array}$} & \multirow[b]{2}{*}{$\begin{array}{l}\mathrm{OM}^{*} \\
(\%)\end{array}$} & \multirow[b]{2}{*}{$\begin{array}{c}\mathrm{CEC} \\
\left(\mathrm{cmol}_{\mathrm{c}} /\right. \\
\mathrm{kg})\end{array}$} & \multicolumn{4}{|c|}{$\begin{array}{l}\text { Exchangeable cation } \\
(\mathrm{cmolc} / \mathrm{kg})\end{array}$} & \multicolumn{5}{|c|}{ Particle size distribution (\%) } \\
\hline & & & & & & $\mathrm{Ca}$ & $\mathrm{Mg}$ & $\mathrm{K}$ & $\mathrm{Na}$ & $\begin{array}{l}\text { Clay } \\
(<2 \\
\mu \mathrm{m})\end{array}$ & $\begin{array}{l}\text { Silt } \\
(2-20 \\
\mu \mathrm{m})\end{array}$ & $\begin{array}{c}\text { Fine sand } \\
(20-200 \\
\mu \mathrm{m})\end{array}$ & $\begin{array}{c}\text { Coarse sand } \\
(200-1,000 \\
\mu \mathrm{m})\end{array}$ & Texture** \\
\hline SS 1 & 6.2 & 5.9 & 0.05 & 3.6 & 26.4 & 17.0 & 2.2 & 0.43 & 0.12 & 37.3 & 28.7 & 13.7 & 20.3 & CL \\
\hline SS 2 & 5.8 & 5.7 & 0.06 & 2.8 & 20.1 & 15.0 & 2.0 & 0.47 & 0.16 & 36.5 & 29.4 & 15.2 & 18.9 & CL \\
\hline SS 3 & 6.1 & 6.0 & 0.06 & 2.4 & 19.2 & 13.2 & 2.5 & 0.51 & 0.18 & 37.2 & 28.5 & 14.3 & 20.0 & CL \\
\hline SS 4 & 6.1 & 5.9 & 0.07 & 2.0 & 18.0 & 12.5 & 2.4 & 0.56 & 0.14 & 38.5 & 26.5 & 13.2 & 21.8 & CL \\
\hline SS 5 & 6.4 & 5.8 & 0.08 & 1.6 & 16.7 & 11.3 & 3.3 & 0.62 & 0.23 & 44.1 & 26.6 & 12.1 & 17.2 & CL \\
\hline SS 6 & 6.2 & 5.5 & 0.07 & 1.7 & 18.5 & 15.0 & 2.9 & 0.55 & 0.24 & 42.1 & 25.1 & 13.2 & 19.6 & CL \\
\hline SS 7 & 6.6 & 5.8 & 0.07 & 1.8 & 22.9 & 17.6 & 2.6 & 0.52 & 0.26 & 42.8 & 34.5 & 10.0 & 12.7 & CL \\
\hline SS 8 & 6.2 & 5.8 & 0.08 & 1.4 & 16.9 & 14.0 & 3.7 & 0.52 & 0.35 & 48.3 & 31.2 & 8.9 & 11.6 & CL \\
\hline SS 9 & 6.2 & 6.0 & 0.09 & 2.0 & 19.2 & 13.2 & 3.2 & 0.54 & 0.31 & 45.6 & 28.5 & 9.3 & 16.6 & CL \\
\hline SS 10 & 5.8 & 5.5 & 0.13 & 2.6 & 22.9 & 17.3 & 3.6 & 0.63 & 0.21 & 40.8 & 25.1 & 15.6 & 18.5 & CL \\
\hline
\end{tabular}

*OM: Organic Matter Content

**Texture: CL: Clay Loam 


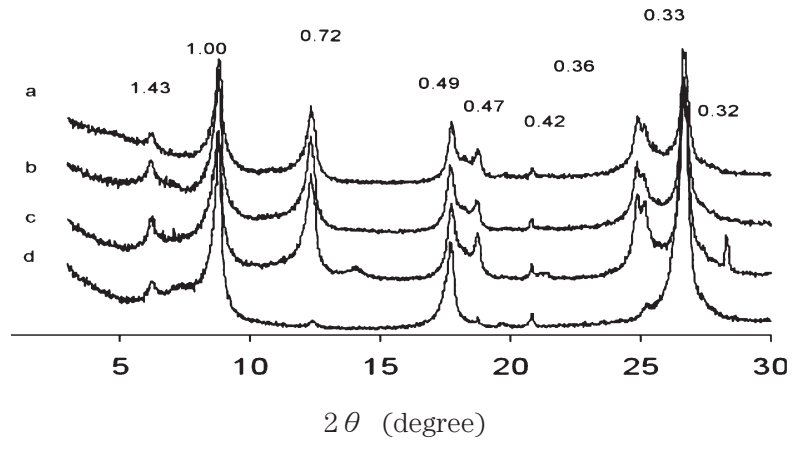

Fig. 2. X-ray patterns of the $<2 \mu \mathrm{m}$ clay fraction of sediment (SD 4). Spacing is in nm.

Treatments: a, Mg-saturation and glycerol - salvation;

b, Mg-saturation and air-drying;

c, K-saturation and air-drying;

d, $\mathrm{K}$-saturation and heating at $500^{\circ} \mathrm{C}$

Table 3. Clay mineral contents in $<2 \mu$ m clay fractions of the soil samples

\begin{tabular}{lrrrrc}
\hline \multirow{2}{*}{ Location } & \multicolumn{5}{c}{ Clay mineral contents (\%) } \\
\cline { 2 - 6 } & Mc* & Ch & Kt & Qz & Fd \\
\hline SS 1 & 30 & 12 & 23 & 30 & 5 \\
SS 2 & 30 & 10 & 21 & 39 & + \\
SS 3 & 31 & 11 & 20 & 38 & + \\
SS 4 & 38 & 9 & 19 & 42 & + \\
SS 5 & 45 & 7 & 18 & 30 & + \\
SS 6 & 47 & 5 & 14 & 34 & + \\
SS 7 & 50 & 6 & 17 & 27 & + \\
SS 8 & 40 & 10 & 20 & 25 & 5 \\
SS 9 & 42 & 9 & 20 & 24 & 5 \\
SS 10 & 38 & 11 & 17 & 34 & 0 \\
\hline
\end{tabular}

*. Mc: Mica; Ch: Chlorite; Kt: Kaolinite; Qz: Quartz; Fd: Feldspar

+. Not detected

imen. The peaks at 0.42 and $0.33 \mathrm{~nm}$ and at around $0.32 \mathrm{~nm}$ indicate quartz and feldspar, respectively.

The relative percentage of clay minerals of soil samples was calculated based on the peak intensity of the minerals (Nguyen and Egashira, 2005) and the results are given in Table 3. Mica and quartz were predominant with a range of $30-50 \%$ and $27-42 \%$, respectively, followed by kaolinite and chlorite. The mineral composition thus obtained was similar to that reported by Ho et al., (1998) for soil in farmland $15 \mathrm{~km}$ distant from our study site. Soils in both farmlands are derived from fine particles transported by the Red River. A similar mineral composition was found in farmland soil along the To Lich and Kim Nguu Rivers (Huonget al., 2010a, 2008b).

\section{Heavy Metal Concentration in the Soil}

The mean value of four times taking for one location of total heavy metal concentrations in the soil samples are shown in Table 4. The concentration of the
Table 4. Total heavy metal concentration in the soil samples

\begin{tabular}{ccccccc}
\hline \multirow{2}{*}{ Location } & $\mathrm{Cd}$ & $\mathrm{Cr}$ & $\mathrm{Cu}$ & $\mathrm{Pb}$ & $\mathrm{Zn}$ & $\mathrm{Ni}$ \\
\cline { 2 - 7 }$(\mathrm{mg} / \mathrm{kg})$ \\
\hline SS 1 & 1.2 & 42 & 22 & 30 & 127 & 26 \\
SS 2 & 2.6 & 60 & 42 & 49 & 139 & 39 \\
SS 3 & 1.4 & 49 & 60 & 58 & 150 & 42 \\
SS 4 & 1.9 & 50 & 62 & 65 & 157 & 57 \\
SS 5 & 2.4 & 50 & 61 & 86 & 245 & 54 \\
SS 6 & 2.4 & 49 & 58 & 75 & 225 & 43 \\
vbSS 7 & 2.3 & 46 & 55 & 72 & 203 & 41 \\
SS 8 & 2.3 & 43 & 55 & 72 & 215 & 51 \\
SS 9 & 1.8 & 43 & 49 & 60 & 156 & 43 \\
SS 10 & 1.3 & 42 & 35 & 55 & 119 & 38 \\
\hline BGL* & 1.2 & 42 & 43 & 32 & 115 & 34 \\
\hline MOSTE** & 2 & & 50 & 70 & 200 \\
\hline
\end{tabular}

*. Background levels of heavy metals in agricultural soils of Tu Liem District of Hanoi, Vietnam

**. MOSTE 2008: Vietnamese standard for heavy metal concentration in agricultural soils

heavy metals of the soil was in the range of $22-62 \mathrm{mg} /$ $\mathrm{kg}$ for $\mathrm{Cu}, 30-86 \mathrm{mg} / \mathrm{kg}$ for $\mathrm{Pb}, 119-245 \mathrm{mg} / \mathrm{kg}$ for $\mathrm{Zn}$, $1.2-2.6 \mathrm{mg} / \mathrm{kg}$ for $\mathrm{Cd}, 42-60 \mathrm{mg} / \mathrm{kg}$ for $\mathrm{Cr}$, and $26-57 \mathrm{mg} /$ $\mathrm{kg}$ for Ni. The metal concentrations tended to increase toward the sampling locations from upstream to the centre of river and then decrease toward to downstream. This would be the result of settlement of heavy metalsorbed suspended solids in irrigation water during its flowing in channels from the pumping stations to the remote sampling locations.

For the sewage irrigated soil, greater amounts of heavy metals were observed, especially for $\mathrm{Cd}, \mathrm{Zn}, \mathrm{Pb}, \mathrm{Cr}$ (Chen et al., 2007). According to Yamadera and Suzuki (2004), soil of Hanoi city general developed on alluvial deposit from Red river. Mica as well as a kaolinite and chlorite dominate clay minerals over the whole region. Thus, there is no big difference in the parent material of soils. Therefore, the great elevation of heavy metal concentrations in soil of study area can be considered to result from using polluted irrigation water.

Compared with the background level of heavy metals in the soil that has not been subjected to polluted irrigation water (Ho et al., 1998), the heavy metal concentration exhibited higher values in all locations of the study site except $\mathrm{SS} 1$ for $\mathrm{Cu}, \mathrm{Pb}$ and $\mathrm{Ni}$, and the metal concentrations for $\mathrm{Cd}, \mathrm{Cu}$ and Pbof soil samples SS 3 SS 8exceeded the permissible level of the Vietnamese standard (MOSTE, 2008) for agricultural soil (Cd: $2 \mathrm{mg} /$ $\mathrm{kg}$; $\mathrm{Cu}: 50 \mathrm{mg} / \mathrm{kg}$; Pb: $70 \mathrm{mg} / \mathrm{kg}$ ). These indicate that the excess heavy metal concentrations in the soil are mainly due to the application of polluted irrigation water to the farmland. Yet, metal concentrations in the soil samples were much lower than the concentrations in the farmland irrigated from the heavily polluted To Lich and Kim Nguu Rivers (Nguyen et al., 2008b). In the long term, irrigation would cause the accumulation of heavy 
Table 5. Correlation coefficients among the chemical properties of the soil samples

\begin{tabular}{|c|c|c|c|c|c|c|c|c|c|c|}
\hline & $\mathrm{pH}$ & Clay & CEC & $\mathrm{OM}$ & $\mathrm{Cd}$ & $\mathrm{Cr}$ & $\mathrm{Cu}$ & $\mathrm{Ni}$ & $\mathrm{Pb}$ & $\mathrm{Zn}$ \\
\hline $\mathrm{pH}$ & 111 & 0.47 & -0.33 & -0.48 & 0.35 & 0.40 & 0.37 & 0.42 & 0.4 & 0.36 \\
\hline Clay & & 1 & 0.93 & 0.91 & 0.95 & 0.97 & 0.92 & 0.96 & 0.94 & 0.93 \\
\hline CEC & & & 1 & 0.86 & -0.96 & -0.97 & -0.97 & -0.98 & -0.98 & -0.99 \\
\hline $\mathrm{OM}$ & & & & 1 & -0.95 & -0.86 & -0.97 & -0.83 & -0.91 & -0.87 \\
\hline $\mathrm{Cd}$ & & & & & 1 & 0.96 & 0.95 & 0.96 & 0.98 & 0.94 \\
\hline $\mathrm{Cr}$ & & & & & & 1 & 0.97 & 0.99 & 0.97 & 0.98 \\
\hline $\mathrm{Cu}$ & & & & & & & 1 & 0.98 & 0.99 & 0.98 \\
\hline $\mathrm{Ni}$ & & & & & & & & 1 & 0.98 & 0.98 \\
\hline $\mathrm{Pb}$ & & & & & & & & & 1 & 0.99 \\
\hline $\mathrm{Zn}$ & & & & & & & & & & 1 \\
\hline
\end{tabular}

${ }^{*}$ Correlation coefficient greater than 0.83 is significant at $1 \%$ level

metals in the soil at a toxic concentration level and adversely affect both soil microbiological process and plant growth.

Compared with the background level of heavy metals in the soil that has not been subjected to polluted water irrigation (Ho et al., 1998), heavy metals in almost locations of the study site exhibited higher concentration, and the total concentrations of $\mathrm{Cd}, \mathrm{Cu}$ and Pbexceeded the permissible level of the Vietnamese standard for agricultural soil (MOSTE, 2008). These indicate that the excess heavy metal concentrations in the study site can be attributed mainly to the application of polluted irrigation water to the soil.

From Tables 1 and 4 shows that the higher metal concentrations in the water lead to the higher metal concentration in the soil samples. These results indicate that heavier water pollution leads to higher heavy metal concentration in the soil, and the effect of heavy metal pollution of the water on the agricultural soil is different according the type of heavy metal.

The source of heavily polluted is the water from the To Lich and Kim NguuRivers with extremely high suspended solid concentration (Nguyen et al., 2008a). Through irrigation, suspended solids of the Nhue River are transported into the agricultural field, and the related metals accumulated in the soil.

Table 5 shows the correlation coefficients among the chemical properties of the soil samples. The correlation coefficient was significant at 1\% level among the chemical properties excepting $\mathrm{pH}$.

\section{CONCLUSIONS}

The concentrations of $\mathrm{Cr}, \mathrm{Cd}, \mathrm{Cu}, \mathrm{Pb}, \mathrm{Zn}$ and $\mathrm{Ni}$ in the soil at the sampling sites affected by the polluted water from the Nhue River exceeded the permissible level of Vietnamese standard for agricultural soil. Metals concentration in the soils increased with increasing metal concentrations in water. These results indicate that the heavier pollution of the water led to the higher metal concentration in the soil.

\section{ACKNOWLEDGMENT}

This research is funded by Vietnam National Foundation for Science and Technology Development (NAFOSTED) under grant number 105.99-2011.06.

\section{REFERENCES}

Committee of Soil Standard Methods for Analyses and measurements 1986 Soil Standard Methods for Analyses and Measurements. Hakuyusha, Tokyo

Chen, Z., K. Sakurai, Y. Kang and K. Iwasaki 2007 Concentration and chemical forms of heavy metals in urban soils of Shanghai, China. Soil Science and PlantNutrition, 53: 517-529

Feigin, A., L. Ravina and J. Shalhevet 1991 Irrigation with treated sewage effluent. Springer, Berlin

Ho, T. L. T., X. P. Hoang and K. Egashira 1998 Chemical, physical and mineralogical properties of soils in TuLiem and Thanh Tri districts of Hanoi city, Vietnam. Journal of Faculty Agricultural, Kyushu University, 43: 281-291

Ho, T. L. T. and K. Egashira 2000 Heavy metal characterization of river sediment in Hanoi, Vietnam. Communication in Soil Science and Plant Analysis, 31: 2901-2916

Kikuchi, T., T. Furuichi, T. H. Huynh and S. Tanaka 2009 Assessment of heavy metal pollution in river water of Hanoi, Vietnam using multivariate analyses. B Environmental Contamination Toxicity, DOI 10.1007/s001128-009-9815-4

Klank, L. T., T. A. Vuong, D. C. Phung and A. Dalsgaard 2006 KVL and NIHE partner food quality report for Hanoi and Phnom Penh microbiological part. In "Food safety of aquatic plants and fish raised in wastewater-fed ponds", Production in Aquatic Peri - Urband Systems in Southeast Asia. INCO: International Scientific Cooperation projects (1998-2002)

Mapanda, F., E. N. Mangwayana, J. Nyamangara and K. E. Giller 2005 The effect of long-term irrigation using wastewater on heavy metal contents of soils under vegetables in Harare, Zimbabwe. Agricultural Ecosystem Environment, 107: 151165

Ministry of Science Technology and Environment, Vietnam (MOSTE) 2008 The standard for the quality of Water and Soil

Muramoto, J., I. Gotoand and M. Ninaki 1992 Rapid analysis of the exchangeable cations and cation exchange capacity (CEC) 
to the soil by sacking extraction method. Soil Science and Plant Nutrition, 63: 210-215

Nguyen, T. L. H., M. Ohtsubo, Y. L. Loretta., T. Higashi and M. Kanayama 2010a Heavy metal contamination of soil and vegetable in wastewater-irrigated agricultural field in a suburban area of Hanoi, Vietnam. Communication in Soil Science and Plant Analysis, 41(4): 290-307

Nguyen, T. L. H., M. Ohtsubo, Y. L. Loretta., T. Higashi and M. Kanayama 2008a Assessment of water quality of two rivers in Hanoi City and its suitability for irrigation water. Paddy Water Environment, 6: 257-262

Nguyen, T. L. H., M. Ohtsubo, Y. L. Loretta, T. Higashi and M. Kanayama 2008b Heavy metal contamination of soil and rice in wastewater-irrigated paddy field in a suburban area of Hanoi, Vietnam. Clay Science, 13: 205-215

Nguyen, T. L. H., M. Ohtsubo, Y. L. Loretta and T. Higashi 2007b Mobility of heavy metals in the sediment of the To Lich River and the Kim Nguu River in Hanoi City. Journal of Agricultural Faculty, Kyushu University, 52 (1): 179-185

Nguyen, Q. H and K. Egashira 2005 Clay mineralogy of alluvial soils from different river systems/agro-ecological regions in Vietnam in reference to origin, regional distribution and soil quality. Clay Science, 12(6): 349-360

Singh, K. P., D. Mohon., S. Sinha and R. Dalwani 2004 Impact assessment of treatment/untreated wastewater toxicants discharge by sewage treatment plants on health, agricultural, and environmental quality in wastewater disposal area. Chemos, 55: $227-255$

Trinh, A. D., G. Vachaud, M. P. Bonnet, N. Prieur, D. L. Vu and L. A Le 2007 Experimental investigation and modeling approach of the impact of urban waste on a tropical river: a case study of the Nhue River, Hanoi, Vietnam. Journal of Hydrology, 334: 347-358 